\title{
Functional properties of multicomponent galvanic alloys of iron with molybdenum and tungsten
}

\author{
A.V.Karakurkchi, M.V.Ved', N.D.Sakhnenko, \\ I.Yu.Yermolenko, S.I.Zyubanova, Z.I.Kolupayeva \\ National Technical University "Kharkiv Polytechnic Institute", \\ 21 Frunze St., 61002 Kharkiv, Ukraine
}

Received January 22, 2015

\begin{abstract}
Galvanic alloy coatings Fe-Mo (W) and Fe-Mo-W were deposited from citrate bath based on Fe (III) using both direct and pulsed current on substrates steel 3 and grey cast iron GC 18. It was shown that the alloying components content, their distribution on the surface, morphology and topography of the coatings are depended on the electrolysis mode. It was established that the functional properties of the binary and ternary alloys of iron (corrosion resistance, microhardness, antifriction et al.) exceed parameters of the substrate and are predetermined by the composition, structure, material and surface roughness.

Keywords: iron alloys, refractory metals, electrochemical synthesis, functional properties, direct current, pulsed electrolysis, citrate electrolyte, corrosion resistance, frictional properties, wear resistance.
\end{abstract}

Электролитические покрытия сплавами $\mathrm{Fe}-\mathrm{Mo}(\mathrm{W})$ и $\mathrm{Fe}-\mathrm{Mo}-\mathrm{W}$ получены из цитратного электролита на основе $\mathrm{Fe}$ (III) в гальваностатическом и импульсном режимах на подложках из стали 3 и серого чугуна СЧ 18. Показано, что содержание легирующих компонентов, их распределение по поверхности, морфология и топография покрытий зависят от режима нанесения. Установлено, что функциональные свойства бинарных и тернарных сплавов железа (коррозионная стойкость, микротвердость, антифрикционные и др.) превышают показатели подложки и предопределяются составом, структурой материала и шероховатостью поверхности.

Функціональні властивості багатокомпонентних гальванічних сплавів заліза з молібденом і вольфрамом. Г.В.Каракуркчі, М.В.Ведь, М.Д.Сахненко, І.Ю.Срлоленко, С.І.Зюбанова, З.І.Колупаєва.

Електролітичні покриття сплавами Fe-Mo (W) i Fe-Mo-W одержано з цитратного електроліту на основі $\mathrm{Fe}$ (III) у гальваностатичному та імпульсному режимах на підкладках зі сталі 3 та сірого чавуну СЧ 18. Показано, що вміст легуючих компонентів, їх розподіл вздовж поверхні, морфологія і топографія покриттів залежать від режиму нанесення. Встановлено, що функціональні властивості бінарних і тернарних сплавів заліза (корозійна стійкість, мікротвердість, антифрикційні тощо) обумовлені складом, структурою матеріалу і шорсткістю поверхні.

\section{Introduction}

Properties of the working surfaces of machines and mechanisms parts and elements determine their reliability and durability. In this regard, the search for effec- tive ways to improve the physico-mechanical properties and corrosion resistance of construction metals and alloys is going on.

The working characteristics of the materials can be effectively enhanced by superposition of thin layer electroplatings of cer- 
tain purpose. The technological simplicity of the process with small amount of material, the possibility of forming systems that are difficult to obtain by chemical or metallurgical ways, as well as the variation in coating properties depending on the nature of codeposited components determine the expediency and the prospect of their use in industry.

Currently, the electrochemical technologies of metal plating by binary and ternary alloys of iron with chromium, nickel, copper, tungsten, titanium and other metals become widespread [1]. Such alloys are characterized by absence of internal stress, high deposition rate, a wide range of applied thickness, good adhesion to the base metal, as well as higher indexes of wear and corrosion resistance in aggressive environments. In this case elimination of the drawbacks, that are inherent to the electroplating iron, is explained by implantation of the alloying components.

Choice of the alloy components for electroplating is based on a wide experience in the use of the alloy steels and dependences of their functional properties on the composition [2]. That is why the implantation of molybdenum and wolfram in the iron-based coatings predictably will enhance the physico-mechanical properties (microhardness, wear resistance) and corrosion resistance of the alloy obtained.

Currently, for formation of the binary coatings the ammonium citrate electrolytes based on Fe (II) are used [3-5]. However, the resulting coatings are characterized by exiguous content of the alloying components at low current efficiency, and electrolyte are characterized by short time stability, that have been explained by occurrence of the side reactions like oxidation of Fe (II) to $\mathrm{Fe}$ (III) by atmospheric oxygen as well as in the anodic process and intense evolution of hydrogen from the acidic electrolyte. Besides, the presence of ammonium ions in the solution requires additional activities of wastewater purification and the working personnel safety.

A number of studies [6, 7] shown the feasibility of using the citrate complex electrolytes based on Fe (III) salts for iron codeposition with molybdenum and tungsten. Due to eliminating of the side reactions the increasing of molybdenum content in the binary Fe-Mo alloy and current efficiency [812] in comparison with the known electrolytes based on iron (II) $[4,5]$ became possible.
The aim of this work was to study the influence of composition and morphology on the functional properties of electrochemical coatings of multicomponent alloys Fe-Mo (W) and Fe-Mo-W, deposited from citrate electrolytes based on Fe (III) in the galvanostatic and pulse modes on mild steel substrate and cast iron.

\section{Experimental}

The coatings were formed on substrates of steel 3 and cast iron GC 18, surface pretreatment of which was performed by the standard technique [13].

The coatings were deposited from electrolyte of the following composition, $\mathrm{mol} \cdot \mathrm{dm}^{-3}$ : $\mathrm{Fe}_{2}\left(\mathrm{SO}_{4}\right)_{3}-0.1 \ldots 0.15 ; \mathrm{Na}_{2} \mathrm{MoO}_{4}-$ $0.06 \ldots 0.08$ and/or $\mathrm{Na}_{2} \mathrm{WO}_{4}-0.04 \ldots 0.06$; $\mathrm{Na}_{3} \mathrm{Cit}-0.2 \ldots 0.3 ; \mathrm{Na}_{2} \mathrm{SO}_{4}-0.1 ; \mathrm{H}_{3} \mathrm{BO}_{3}$ - 0.1. The acidity of the electrolyte was adjusted with $\mathrm{NaOH}$ or $\mathrm{H}_{2} \mathrm{SO}_{4}$ and was maintained in the interval $\mathrm{pH} 3.0 \ldots 4.0$. Working solutions were prepared from chemicals of reagent grade and distilled water.

Electrosynthesis was carried out in two modes: galvanostatic mode at the current density $i 3.0 \ldots 6 \mathrm{~A} \cdot \mathrm{dm}^{-2}$; and pulse mode by varying the amplitude of the unipolar current $3.5 \ldots 6 \mathrm{~A} \cdot \mathrm{dm}^{-2}$, pulse duration ton $5 \ldots 10 \mathrm{~ms}$ and pause duration toff $10 \ldots 20 \mathrm{~ms}$, at the temperature $20 \ldots 25^{\circ} \mathrm{C}$. The anode was a plate of stainless steel AISI, the ratio of the cathode to anode area was $1: 10$. To form the coatings in the galvanostatic mode stabilized DC power source B5-47 series was used. Pulse electrolysis was carried out at the laboratory complex, which includes a potentiostat PI-50-1.1 with programmer PR-8 and a computer equipped with a card for automatic on-line data registration with the specially designed program to digitize the measurement results.

Efficiency of the electrode process (current efficiency, $C_{e}$ ) was determined by gravimetric method considering the electrochemical equivalent of the alloy [14]. Thickness of the resulting coatings was calculated from the actual increasing of the samples weight during the electrolysis.

Chemical composition of the coatings was examined by X-ray photoelectron spectroscopy using energy dispersive spectrometer INCA Energy 350. The surface morphology was evaluated from the images obtained using scanning electron microscope (SEM) ZEISS EVO 40XVP registering secondary electrons (BSE) during scanning the pat- 

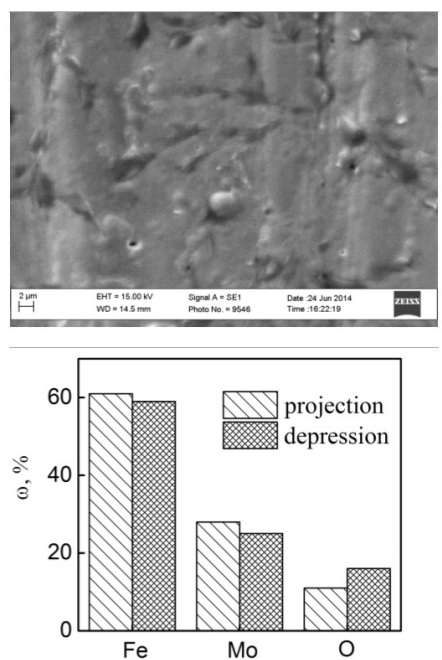

a)
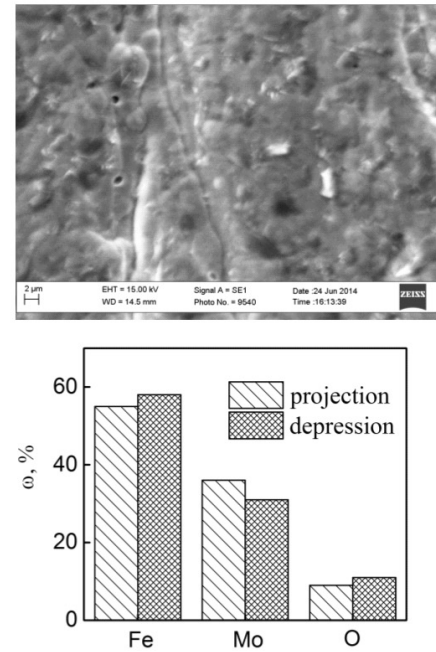

a')
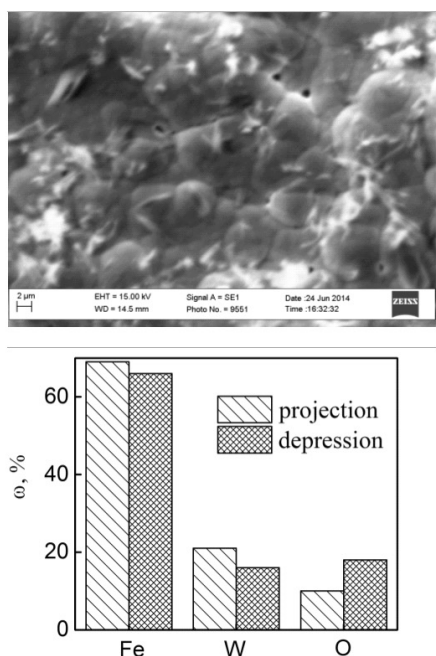

b)
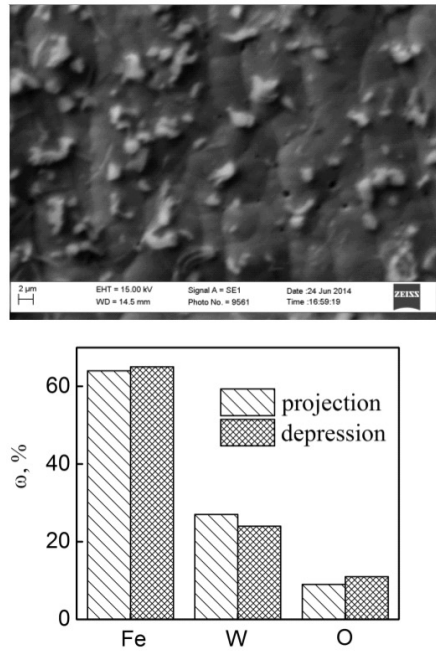

b')
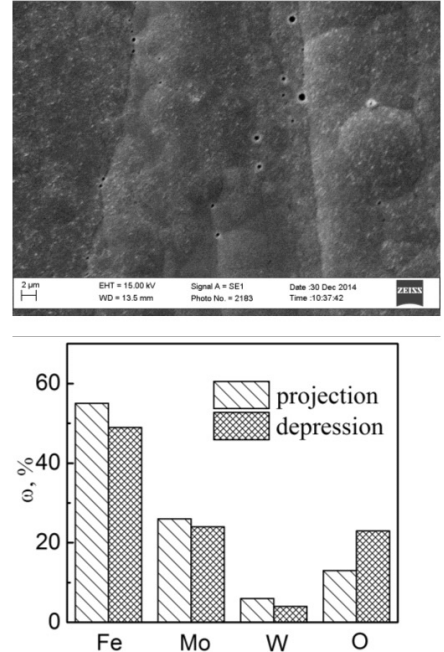

c)
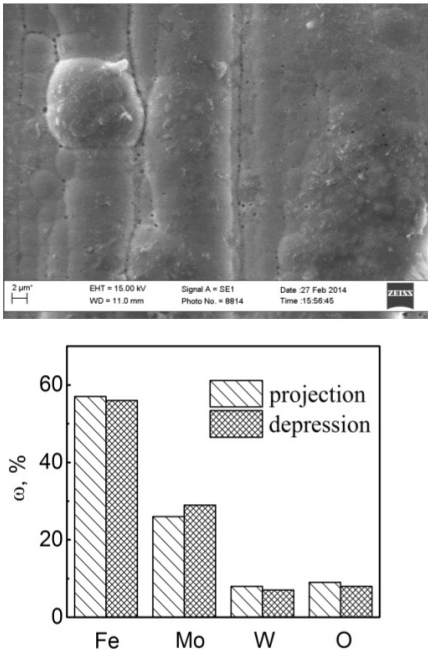

c')

Fig. 1. Morphology and mass concentration ( $\omega, \%)$ of alloying elements in Fe-Mo (a), Fe-W (b), Fe-Mo-W (c) coatings obtained by stationary $(\mathrm{a}, \mathrm{b}, \mathrm{c})$ electrolysis and unipolar pulsed current (a', $\left.\mathrm{b}^{\prime}, \mathrm{c}^{\prime}\right)$. Temperature was $25^{\circ} \mathrm{C}, \mathrm{pH}$ of the electrolyte was $3 \ldots .4$, deposition time -30 min. Magnifi-

terns by electron beam. Evaluation of surface roughness of the formed electrolytic alloys was performed using scanning probe microscope AFM NT-206 (probe CSC-37 cantilever $\mathrm{B}$, the radius of the probe rounding was $10 \mathrm{~nm}$ ) by the contact method on a sample with $10 \times 10 \times 2 \mathrm{~mm}^{3}$ size. The phase composition of the coatings was studied by $\mathrm{X}$-ray structural analysis. The surveys were performed on DRON-2.0 diffractometer in the emission of iron anode.

Physico-mechanical properties of the obtained coatings were evaluated according to metallographic studies of the sections. The quality of adhesion to the base metal was established by polishing methods using polishing paste based on chromium oxide, the bending angle of $90^{\circ}$ and heating up to the temperature $150 \ldots 200^{\circ} \mathrm{C}$, followed by cooling in air.

Microhardness $H \mu$ was measured using a PMT-3 microdurometer with a diamond pyramid under load of $F=50 \mathrm{~g}$ and $100 \mathrm{~g}$.

Studies of antifriction properties of the coating were performed on serial friction machine 2070 SFM-1 by the scheme "discshoe" in the load range of $0.2 \ldots 1.0 \mathrm{kN}$ at sliding speed of $1.3 \mathrm{~m} \cdot \mathrm{s}^{-1}$.

Corrosion tests were carried out in the model media of different acidity: $3 \%$ sodium chloride solution ( $\mathrm{pH} 7$ ) and 1 M sodium sulphate solution at $\mathrm{pH} 3$ and 11 . The base metal and the coating corrosion rate were determined by the polarization resistance technique analyzing the cathode and 

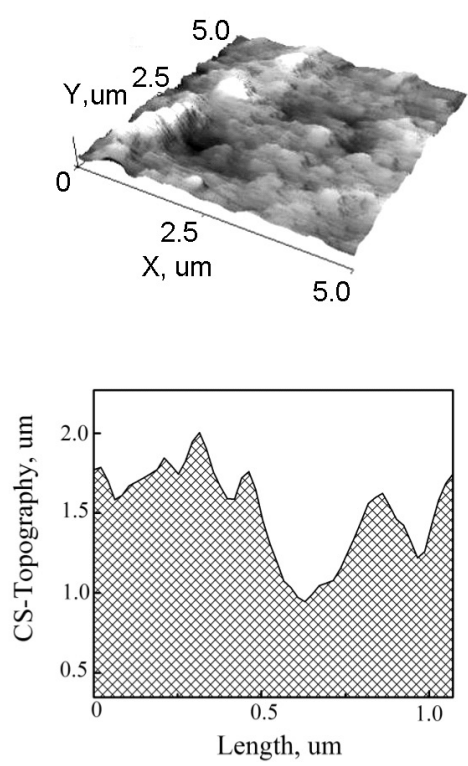

a)
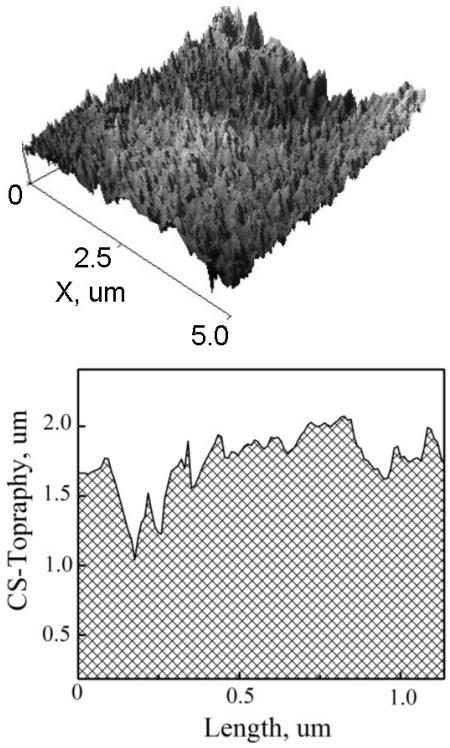

b)
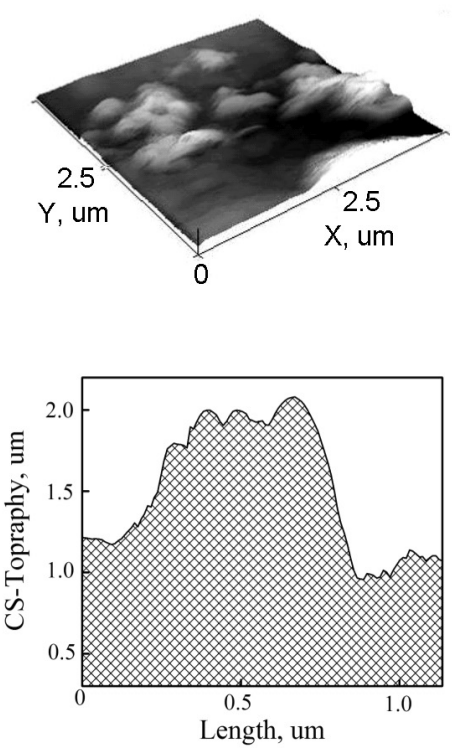

c)

Fig. 2. 3D-surface maps and cross sections of Fe-Mo (a) Fe-W (b), Fe-Mo-W (c) coatings. Scanning area AFM $5 \times 5 \mu \mathrm{m}$.

anode polarization dependences in semilogarithmic coordinates [15].

The corrosion resistance of the coatings was evaluated by deep parameter of corrosion $k_{h}\left(\mathrm{~mm} \cdot\right.$ year $\left.^{-1}\right)$, that had been calculated as:

$$
k_{h}=8.76 \cdot k_{e} \cdot i_{c o r} / \rho,
$$

where $k_{e}$ - electrochemical equivalent of alloy, $\mathrm{kg} \cdot \mathrm{C}^{-1}$; $i_{\text {cor }}$ - corrosion current density, $\mathrm{A} \cdot \mathrm{m}^{-2} ; \rho-$ density of the alloy, $\mathrm{kg} \cdot \mathrm{m}^{-3}$.

Electrochemical equivalent $k_{e}$ and density $\rho$ of the alloys were determined considering their quantitative composition [14].

\section{Results and discussion}

The performed studies confirmed the possibility of obtaining regular light shining low porosity coatings of $\mathrm{Fe}$ alloys with Mo and $W$ from the electrolytes based on iron (III) both in galvanostatic mode and by non-stationary electrolysis [9]. The composition and quality of the coating, as well as process efficiency (current efficiency) depend on the ratio of the alloying salts in the electrolyte, $\mathrm{pH}$ and temperature, as well as on the electrolysis mode [10]. It was reported in [8, 11] that binary galvanic alloys based on iron contains up to 40 wt. $\%$ Mo or $W$ and up to 60 wt. \% summary Mo+W - in the ternary ones (on metal phase).
Analysis of composition and morphology of the formed electroplatings shows that besides the main components (Fe, Mo and/or W) (Fig. 1), the coatings also contain a certain amount of oxygen due to adsorption of oxygen from air.

Thus it is necessary to state the irregular distribution of the alloy components on the surface of the coatings that was obtained in the direct current mode: increased metal content was indicated on the projections of the relief and increased oxygen content - in the depressions. Such concentration profile was caused by several reasons: at first, the increased current density at the projections of the coating ensured its enrichment of metals, whereas in the depressions complete reduction of oxometalates was difficult at low current densities so, consequently, the intermediate oxides of refractory elements may include in composition of the sediments. Secondly, the adsorption/desorption and diffusion processes as well as chemical stages of the surface complexes dissociating, that complicating the hole electrochemical alloying process, occurred with a wittingly greater flow rate on the relief projections but in the depressions oxoforms of the electrolyte components may remain. The coatings, been obtained from electrolytes of similar composition but in the pulsed mode, had more uniform components distribution on the surface, and also 
contained lower amount of oxygen (Fig. 1a', $b^{\prime}, c^{\prime}$ ), that could be explained by elimination of the mentioned above limitation in the pause period and features of the alloys electro-crystallization in non-stationary electrolysis conditions [10].

Increasing $\mathrm{pH}$ up to $5.0 \ldots 6.0$, when monooxometalates $\mathrm{MO}_{4}{ }^{2-}$ (where $\mathrm{M}=\mathrm{Mo}$, W) dominate in the electrolyte composition and higher content of alloying elements in the alloy should be provided by facilitating their discharge in comparison with condensed forms $\left(\mathrm{M}_{2} \mathrm{O}_{7}{ }^{2-}\right.$ et al.), did not lead to the desired effect. On the contrary, oxygen content was significantly increased and the stability of the electrolytes and current efficiency were noticeably reduced $(50.0 \ldots 60.0 \%)$, the quality of the coatings was greatly getting worse: cracks appeared, the coating parts exfoliated from the base metal due to the low adhesion. This occurred because of the increasing of the hydrolysis rate and formation of Fe (III) hydroxo-forms in the indicated $\mathrm{pH}$ range and their inclusion in the alloys composition [8, $11]$.

It should be noted that the Fe-W coatings ceteris paribus were more intense and had greater number of the defects (cracks, blisters) with a tendency to exfoliation that, apparently, was determined by the ratio of atoms radius of the codepositioned metals and the phase structure and in general was characteristic for the electrolytic tungsten alloys [16].

Evaluation of the electrolytic alloys surface topography (Fig. 2) allows concluding that the coatings, been deposited in the galvanostatic mode as well as obtained by no stationary electrolysis, had grain size from $70 \ldots 100 \mathrm{~nm}$ to $0.2 \ldots 0.5 \mu \mathrm{m}$. The surface of Fe-Mo (Fig. 2a) and Fe-Mo-W (Fig. 2c) alloys was characterized by presence of agglomerates of spherical grains nanometer range, that was a feature of amorphous structure of the material, whereas the $\mathrm{Fe}-\mathrm{W}$ coatings had expressed fine-crystalline surface morphology with the large grain sizes (Fig. 2b). Investigation of the phase composition of electroplating of iron with molybdenum and tungsten confirmed different materials structure. X-ray diffraction patterns of the Fe-Mo (Fig. 3a) and Fe-Mo-W (Fig. 3b) coatings on the steel substrates were identical. Only system of $\alpha-F e$ diffraction lines was detected on them. Furthermore, quite broad halo (width at half maximum was about $10^{\circ}$ ) at angles of $2 \theta \sim 57^{\circ}$
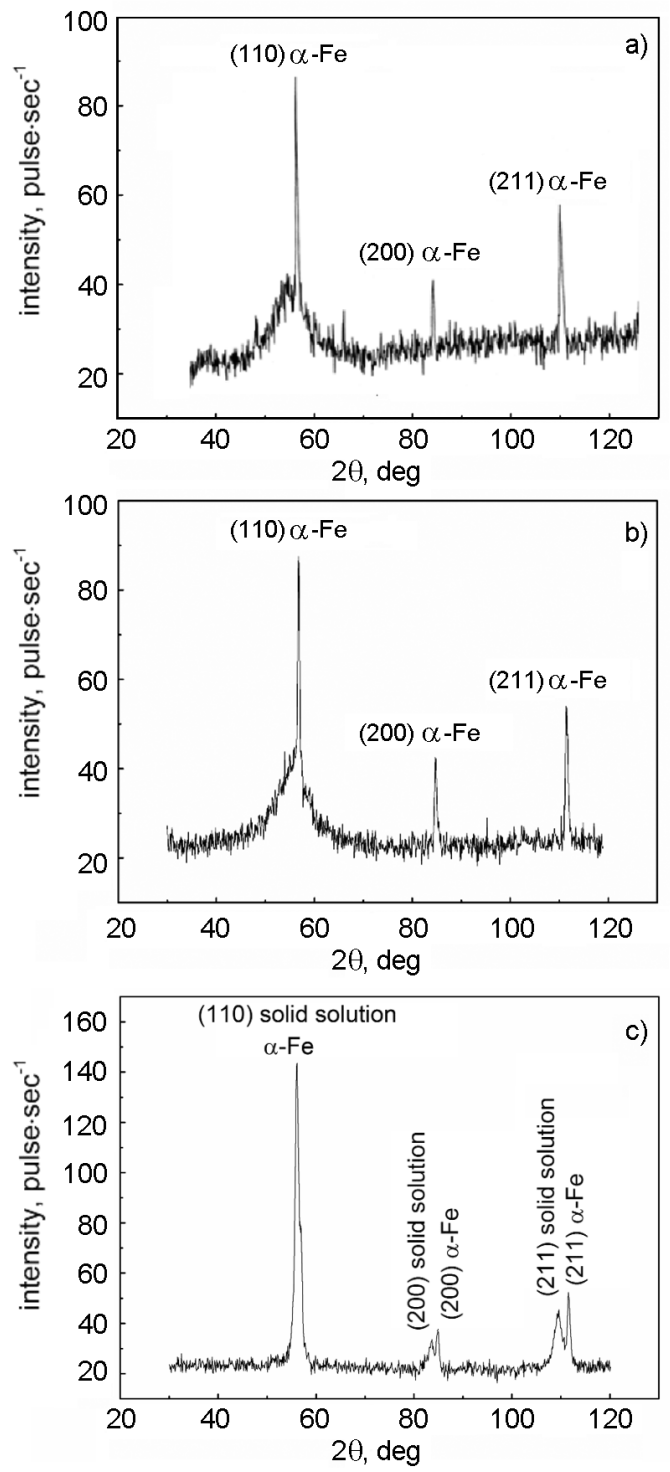

Fig. 3. X-ray diffraction patterns of Fe-Mo (a), Fe-Mo-W (b) and Fe-W (c) coatings on substrate of steel 3 .

was found, that was indicated on the amorphous structure of $\mathrm{Fe}-\mathrm{Mo}$ and $\mathrm{Fe}-\mathrm{Mo}-\mathrm{W}$ coatings. Results of the phase composition analysis of these alloys were in agreement with the data obtained by a number of other researchers [7, 15, 17], and allowed us to suggest that the amorphous alloy structure predetermines improvement of their physicomechanical properties and the low level of internal stresses.

At the same time two systems of diffraction lines, those were corresponding to the phases with body-centered lattice, that were characteristic for alloying components, were visible on the diffraction patterns of the Fe-W coating on the steel 3 (Fig. 3c). One 
Table. Corrosion indicators of tested materials

\begin{tabular}{||c|c|c|c|c|c||}
\hline \hline $\mathrm{pH}$ & $\begin{array}{c}\text { Corrosion } \\
\text { indicators }\end{array}$ & Fe-Mo coating & Fe-W coating & Fe-Mo-W coating & $\begin{array}{c}\text { Substrate Steel } \\
\text { No. 3 }\end{array}$ \\
\hline \multirow{2}{*}{3} & $E_{\text {cor }}, \mathrm{V}$ & -0.25 & -0.24 & -0.26 & -0.62 \\
& $k_{h}, \mathrm{~mm} / \mathrm{year}$ & 0.038 & 0.040 & 0.039 & 1.85 \\
7 & $E_{\text {cor }}, \mathrm{V}$ & -0.37 & -0.35 & -0.32 & -0.56 \\
& $k_{h}, \mathrm{~mm} / \mathrm{year}$ & 0.04 & 0.039 & 0.039 & 0.93 \\
\multirow{3}{*}{11} & $E_{\text {cor }}, \mathrm{V}$ & -0.36 & -0.037 & -0.34 & -0.43 \\
& $k_{h}, \mathrm{~mm} / \mathrm{year}$ & 0.028 & 0.028 & 0.028 & 0.12 \\
\hline
\end{tabular}

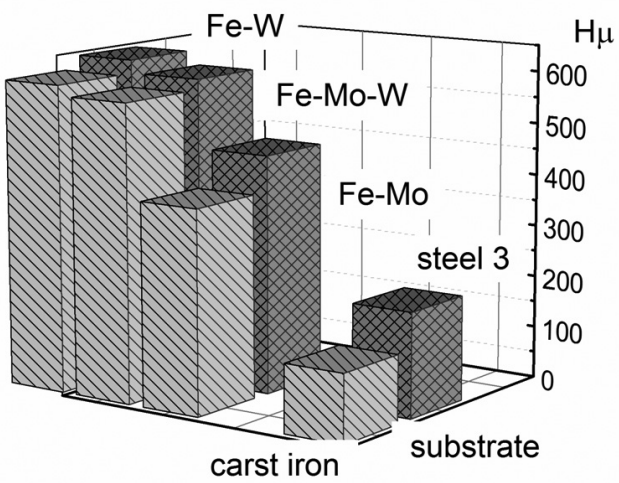

Fig. 4. Microhardness of Fe-Mo (W) and FeMo-W coatings, formed on substrates of steel 3 and cast iron GC 18 .

system of more narrow lines $\alpha-\mathrm{Fe}$ (base metal) and the second system were corresponded to the solid solution of tungsten in $\alpha-F e$.

The phase composition of the Fe-W coating in view of sufficiently high (up to $25 . . .30$ wt. $\%$ ) content of tungsten in the alloy obtained predetermine the high level of the internal stress, and as a consequence, tendency to cracking and poor adhesion to the base metal.

Study of corrosion resistance of the FeMo (W) and Fe-Mo-W coating confirmed the increased chemical resistance of these alloys in all environments studied in comparison with the base metal (steel 3) (Table), that was quite predictable experimental confirmation of the working hypothesis forming the basis for synthesis of the alloys. Improvement of the corrosion resistance of the alloys mentioned above in acidic medium and in presence of $\mathrm{Cl}^{-}$should be emphasized; this effect was provided by the presence of the alloying components (Mo and W) in the coating composition, that increasing the resistance to pit corrosion as well as the tendency to passivity. Physical-mechanical properties of the coatings were evaluated by

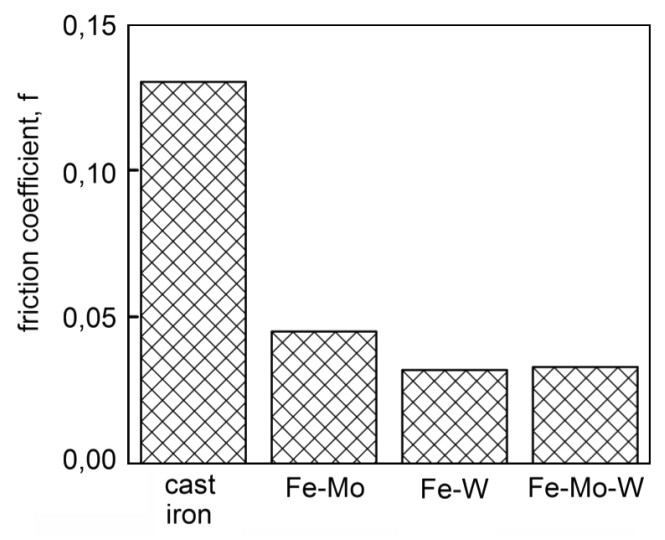

Fig. 5. Friction coefficients of gray cast iron substrate and Fe-Mo (W) and Fe-Mo-W coatings.

the quality of adhesion with the base metal, indexes of microhardness and friction coefficient. It was found that the electroplating of Fe with Mo and W alloys, obtained in the proposed electrolysis modes, have high adhesion to the base metal and maintain it in mechanical (flexural, polishing, a cross-section followed by grinding) and temperature (heating up to $150-200^{\circ} \mathrm{C}$ ) effects.

The microhardness of the electrolytic coatings of iron with refractory metals on the steel 3 in 2.5...3.0 times higher, and for coatings on cast iron GC 18 - in 3.0...3.5 times higher than that of substrate (Fig. 4), and $H \mu$ of tungsten-containing alloys naturally increases the characteristics of Fe-Mo coatings. Investigation of the friction coefficient $f_{f r}$ and the tendency of conjugated materials to scuffing with stepwise loading shown that $f_{f r}$ of investigated coatings in 3.0 to 4.0 times less comparing to these parameters $f_{o}$ iron (Fig. 5), that indicates the high anti-friction properties of the coating. The experimental data on the microhardness and anti-friction properties obtained were in full agreement with the results obtained by other researchers [18].

Thus, complex of the corrosive and physico-mechanical properties of the Fe-Mo 
(W) and Fe-Mo-W alloys electroplating allowed us to consider them as perspective materials in technologies of iron and mild steel parts hardening, as well as in the repair manufacturing in recovery of worn surfaces.

\section{Conclusions}

Uniform shiny coatings of Fe-Mo (W) and Fe-Mo-W alloys on substrates of steel 3 and cast iron GC 18 were obtained in galvanostatic and pulse modes from citrate electrolytes based on Fe (III). The influence of the electrolysis modes and $\mathrm{pH}$ of the electrolyte on the alloying components content, morphology and topography of the surface electrolytic alloys were noted. Use of the unipolar pulse current allows obtaining more uniform in composition and morphology coatings with decreased amount of nonmetallic inclusions and with increased content of molybdenum and tungsten in the valloys. It was found that the Fe-Mo and Fe-Mo-W coatings had amorphous structure with smaller grain size, while the $\mathrm{Fe}-\mathrm{W}$ coatings represented the solid solution of tungsten in iron and had more expressed crystalline structure. The phase composition of the alloys and significant content of the alloying components predetermine the higher physical-mechanical properties and corrosion resistance of the materials. The corrosion rate of these coatings in all corrosive environments tested was lower, and microhardness from 2.0 to 3.5 times higher than these of the material of the base (mild steel, cast iron). The coatings had high adhesion to the base metal and better sliding characteristics comparing to the cast iron.

\section{References}

1. A.Brenner, Electrodeposition of Alloys, Academic Press Inc., New York (1963).

2. N.D.Sakhnenko, P.A.Kapustenko, M.V.Ved', S.G.Zhelavskii, Protection of Metals, 34, 4 (1998).

3. V.N.Gadalov, S.G.Emel'yanov, N.A. Korenevskiy, D.N.Romanenko et al., Uprochnyayushchie Tekhnologi i Pokrytiya, 5D, 6 (2008).

4. RU Patent 2174163 (2000).

5. RU Patent 2192509 (2002).

6. M.Glushkova, T.Bairachna, M.Ved, M.Sakhnenko, MRS Proc., doi: 10, 1557/opl.2012.1672.

7. M.V.Ved, M.D.Sakhnenko, T.M.Bairachna, M.V.Tkachenko, Functional Materials, 15, 4 (2008).

8. M.V.Ved, N.D.Sakhnenko, A.V.Karakurchi, S.I.Zyubanova, Zh. Prikl. Khimii, 87, 3 (2014).

9. UA Patent 94272 (2014).

10. UA Patent 93318 (2014).

11. N.D.Sahnenko, M.V.Ved, A.V.Karakurkchi, Voprosy Khimii i Khimicheskoy Tekhnologii, 4, 4 (2013).

12. UA Patent 86680 (2014).

13. M.V.Ved', N.D.Sakhnenko, K.V.Nikiforov, J. Adhesion Sci. and Techn., 12, 2 (1998).

14. M.O.Glushkova, M.V.Ved', M.D.Sakhnenko, Mater. Sci., 49, 3 (2013).

15. M.V.Ved', T.O.Nenastina, T.M.Bairachna, M.D.Sakhnenko, Mater. Sci., 44, 4 (2008).

16. T.Bairachnaya, M.Ved', N.Sakhnenko, Elektroliticheskie Splavy Vol'frama. Poluchenie i Svoistva, Saarbrucken, LAP LAMBERT Academic Publishing (2013) [in Russian].

17. V.V.Kuznetsov, K.E.Golyanin, T.V.Pshenichkina et al., Mendeleev Commun., 23, 6 (2013).

18. N.Tsyntsaru, A.Dikusar, H.Cesiulis, J.-P.Celis et al., Powder Metallurgy and Metal Ceram., 48, 7 (2009). 